\title{
MCAM Gene
}

National Cancer Institute

\section{Source}

National Cancer Institute. MCAM Gene. NCI Thesaurus. Code C21261.

This gene plays a role in cell adhesion and receptor signaling. 